\title{
Personality preference facets and self-regulatory employability of human resource professionals
}

\begin{abstract}
Scholars interested in investigating the career wellbeing of employees have reported that employability includes a number of person-centred constructs needed to deal effectively with career-related changes in today's economy. This study explored the relationship between employees' self-regulatory employability skills and personality preference facets. A convenience sample $(\mathrm{N}=196)$ of predominantly female $(73 \%)$, black African people $(88 \%)$ in the early stages of their careers $(80 \%<45$ years) participated in the study. A cross-sectional, quantitative research design approach was followed. Descriptive statistics, Pearson product-moment correlations and canonical correlation analysis were performed to achieve the objective of this study. The results yielded significant associations between the variables. The findings add new insights that may be useful for theoretical views on the personality preference facets underpinning employees' self-regulatory employability skills.
\end{abstract}

Keywords: employee work readiness, personality preferences, employability skills

Change, uncertainty and a turbulent working environment have become a reality for all employees in the current world of work. Change thus has to become part of all organisations' strategy if they wish to survive in an increasingly globalised context which is accompanied by high levels of competition and changing market demands (Cullen, Edwards, Casper \& Gue, 2014; Pasmore, 2011). The necessity for innovation from a technological and socio-economic perspective is placing pressure on both employees and organisations to adapt and change continuously in this context (Cullen et al., 2014; Worley \& Mohrman, 2014). The challenges employees face in organisations (such as job insecurity, changes in job roles, pressure to upskill, work overload, unstable relationships, lack of career advancement opportunities and poor work autonomy) have become a current reality for all employees in the current world of work. In order to survive this turbulent organisational context, employees are required to manage change both within themselves and in their organisational and career contexts (Fugate, Kinicki, \& Blake, 2004). Ashford and Black (1996) have found that individual and psychological factors are essential for career-related wellbeing. Several other authors have found that employees' ability and 
willingness to adapt to change are essential to their career development and wellbeing (Coetzee \& De Villiers, 2010; Hall, 2002; Pulakos, Arad, Donovan \& Plamondon, 2000; Rothmann, 2014). As a result, employability has become a burning issue in recent days. Psychologists (especially industrial psychologists) are uniquely qualified to contribute this issue by applying research-based theory in work contexts.

Several authors report that individuals need a specific set of skills, competencies and personality attributes to make them more employable in the new world of work (ACCI, 2002; Clarke, 2008; Coetzee, Schreuder \& Kotze, 2014; Morley, 2001; Potgieter \& Coetzee, 2013; Rothmann, 2014). According to Ebby, Butts and Lockwood (2003), these competencies should promote career success and have an impact on career wellbeing. Rath and Harter (2010) describe career wellbeing as how people occupy their time and liking what they do. Self-regulatory employability may enhance individuals' feeling of being in control of their careers, which in turn enhances their sense of wellbeing (De Cuyper, Bernhard-Oettel, Bernston, De Witte \& Alarco, 2008; De Vries, Grundemann, \& Van Vuuren, 2001; Fugate et al., 2004; Marler, Barringer, \& Milkovich, 2002). Bernston, Bernhard-Oettel and De Cuyper (2007) add that employability reduces the fear of becoming unemployed (as employability provides employees with choices and alternatives during the economic recession) and therefore contributes significantly to the career wellbeing of employees.

According to Fugate et al. (2004), employability has broad implications for a number of facets such as skills sets, labour markets, employee adaptation, career success and wellbeing. Fugate et al. (2004), Coetzee (2014) and Van der Heijde (2014) note that an individual's employability includes a number of person-centred constructs that combine synergistically to assist employees in adapting effectively to the ever-changing circumstances of today's world of work. Several authors have found that employability denotes a psycho-social construct that includes individual characteristics and selfregulatory capacities that nurture adaptive cognition, behaviour and affect, and enhance the individual-work interface (Coetzee, 2014; Hall \& Marvis, 1995; Van der Heijde, 2014). Fugate et al. (2004) argue that employability depends on identifiable personal characteristics that can be assessed and trained. However, it is not clear how individuals' personalities relate to their employability or their self-regulatory employability capacities. 
The present study focuses on the association between individuals' personality preferences (as outlined by the well-known Myers-Briggs theory of personality types [Myers, McCaulley, Quenk \& Hammer, 2003]) and their self-regulatory employability skills (as designed by the self-regulatory employability model proposed by Beukes [2009]). Selfregulatory capacities are regarded as essential for career self-management and adaptation in constantly changing contexts such as the contemporary employment environment (Van der Heijde, 2014). Understanding the influence of personality in expressing self-regulatory career behaviour may contribute to career theory concerned with developing psychological attributes that support the career wellbeing of individuals in the workplace.

\section{Self-regulatory employability}

Beukes (2009) views employability as the application and continuous development of a series of supportive competencies and self-regulatory attributes through developmental stages that enhance an individual's opportunities for obtaining and sustaining employment opportunities. Employability in this context therefore refers to the skills, knowledge, understanding and personal attributes that make a person more likely to choose and secure occupations in which they are satisfied and successful (Beukes, 2009; Pool \& Sewell, 2007).

Beukes (2009) proposed a self-regulatory employability model which consists of a series of stages which allow individuals to channel their employability competencies effectively and thus to access and sustain employment in the highly competitive and turbulent labour market. Figure 1 represents Beukes's (2009) self-regulatory model. Each stage involves a specific developmental task (regarded as a critical outcome of the specific stage), which in turn is supported by a set of core employability competencies. The self-regulatory employability model includes basic skills (such as computer and IT skills, an attitude that recognises the value of maths and the ability to listen to advice); goal-driven behaviour (where individuals set goals, and use their time and resources to achieve these goals); creative learning (the openness of an individual to new ideas, finding creative solutions to problems, an inclination towards life-long learning and the trust in the power of teamwork to reach solutions); communication skills (good communication skills, being able to present information and act as leader in a team situation); and lastly business acumen (an 
understanding and awareness of business and companies, how the individual fits into the workplace through skills, and an awareness of money and finances).

Insert Figure 1 approximately here

Self-regulatory employability is associated with emotional intelligence and positive career behaviours (Coetzee \& Beukes, 2010), career self-management, and learning and goaldirected behaviours that support individuals' employability and career wellbeing (Van der Heijde, 2014).

\section{Personality and self-regulatory employability}

Several authors conclude that employees need numerous person-centred constructs (such as proactive behaviours, personal initiative and proactive personalities) in order to manage the challenges of today's world of work effectively (Bateman \& Crant, 1993; Crant, 2000; Frese \& Fray, 2001). Employees with proactive personalities tend to demonstrate proactive behaviour which enhances career success and wellbeing (Boudreau, Boswell \& Judge, 1999; Fugate et al., 2004). Fugate et al. (2004) posit that by addressing the "who am I" question, and therefore touching on an employee's personality, managers may assist individuals in achieving their personal goals or aspirations, which in turn may lead to employee wellbeing. Furthermore, psychologists have ound that personality characteristics are predictors of career wellbeing, performance and career success (Hogan, ChamorroPremuzic \& Kaiser, 2013; Kuncel, Ones \& Sackett, 2010). Personality is increasingly recognised as a career meta-competency which influences people's self-regulatory employability (Baruch, 2004; Coetzee, 2008, 2014; Fugate et al, 2004; Potgieter, 2012; Sinclair, 2009). Coetzee et al. (2014) have found significant links between the MBTI personality preferences and the psychological career resources that support individuals' self-regulatory employability and career wellbeing.

Jung (1990) suggested that variations in people's behaviour can be explained by distinctive differences in the ways they prefer to take in information, make decisions and generally deal with the world. These differences are expressed in people's personality type preferences. Myers, McCaulley, Quenk and Hammer (2003) define personality type as the 
dominant and conscious predisposition to either act or react in a characteristic manner when observing one's outer world and assigning meaning to each experience. Jung (1960) notes that type is predispositioned within human beings and thus a universal attribute. Katherine Briggs and Isabel Myers extended on the Jungian psychological type theory and developed the well-known Myers-Briggs Type Indicator (MBTI), which is a tool to assist individuals in understanding their own and others' use of natural preferences of mental or cognitive functioning (Myers \& Myers, 1998), and to help them integrate such understanding in their everyday life (Myers et al., 2003).

The MBTI typology includes four pairs of opposite preference facets, called dichotomies or dimensions of personality. These type dichotomies represent the natural ways in which different people use their minds differently (Myers \& Myers, 1998). The first three dichotomies were part of Jung's original theory, and the fourth was added by Briggs and Myers (Garrety, 2007; Leary Reilly \& Brown, 2008; Potgieter \& Coetzee, 2013):

1. Orientation of energy: Extraversion (E) versus Introversion (I), or relative interest in outer (E) and inner (I) worlds.

2. Preferred modes of perception: Sensing (S) versus Intuition $(\mathrm{N})$ - whether people perceive through their senses (S) or through indirect perception by way of the unconscious $(\mathrm{N})$. Sensing people focus on the here and now, and intuitive people prefer to focus on future possibilities.

3. Decision-making: Thinking $(\mathrm{T})$ versus Feeling $(\mathrm{F})$ - whether people make decisions using logic $(\mathrm{T})$ or subjective values $(\mathrm{F})$.

4. Preferences for dealing with the outer world: Judging (J) versus Perceiving (P), which refers to a general method of dealing with the world. Judging people like order and a planned and organised approach to life, and they prefer to have things settled. Perceiving people embrace ambiguity, tend to like a flexible and spontaneous approach to life and prefer to keep their options open.

The MBTI preferences are multifaceted and consist of many distinct but connected facets. The facets (five per dichotomy) of each of the eight preferences (E-I, S-N, T-F, J-P) identify some of the distinctive ways in which people express their personality types (Kummerow \& Quenk, 2003). The MBTI assessment categorises individuals into one of 16 different (equally valuable) personality types. Depending on their preferences reported 
by the MBTI, individuals are identified as extraverted or introverted, sensing or intuitive, thinking or feeling and judging or perceiving. Individuals are given a four-letter designation (eg ESTJ) that indicates their dominant preferences, and therefore their personality type.

While people possess and utilise qualities for both poles of each dichotomy, the MBTI assessment reveals individuals' preference or how they would respond first and what they are most comfortable with (Myers et al., 2003). According to Jung (1971), individuals' natural preferences cause them to develop ways of behaviour and personality patterns which are characteristics of their mental processes.

Using MBTI information, industrial psychologists can assist employees in raising energy and optimism by reframing the way in which they interpret difficulties arising from their differences with others and dealing with the turbulent changes of the current world of work. Higgs (2001) suggests that an individual could develop his or her weaker personality attributes and thereby deliver more rounded behaviour, which could possibly enhance the person's employability and thus also enhance their career wellbeing.

Given the evidence that weaker personality preferences can be developed (Baumeister \& Leary, 1995; Myers et al., 2003; Pool \& Sewell, 2007; Salovey \& Meyer, 1990), and the fact that there is a growing need to develop and enhance individuals' employability skills (Coetzee \& Beukes, 2010; Pool \& Sewell, 2007), it could be interesting to explore how personality preferences influence self-regulatory employability skills. The results could be important for industrial psychologists in that a possible relationship between personality preferences and employability skills may contribute towards employee wellbeing, and therefore result in a more committed employee. De Witte (2006) and Sverke, Hellgren and Naswall (2002) have found that employees with a generally good level of wellbeing are more loyal and less likely to leave an organisation.

There seems to be a paucity of research in the South African context on how individuals' personality preferences relate to their employability skills, especially in South Africa's multicultural organisational context. The aim of this study is to explore whether an individuals' personality preference facets are related to their self-regulatory employability 
skills. This study therefore contributes to the discipline of psychology and career theory by exploring how personality preferences influence the perceptions of individuals' selfregulatory employability. Specifically, by employing canonical correlation analysis, it has sought (1) to ascertain whether a noteworthy relationship exists between the eight set MBTI preference facets (introversion, extraversion, sensing, intuition, thinking, feeling, judging and perceiving) and a set of self-regulatory employability skills, and (2) to identify the variables that contribute the most to this relationship.

\section{Method}

\section{Participants}

A purposive sample of one hundred and ninety six $(\mathrm{N}=196)$ employed adults participated in the study. The participants were enrolled for further studies in the human resource management field at a distance learning higher education institution. They were employed in professional positions in the human resource field and predominantly comprised black people $(88 \%)$ and females in their early career stage $(73 \%)$.

\section{Measuring instruments}

The South African Employability Inventory (SAEI) developed by Beukes (2009) is a selfrated multi-factorial measurement tool designed for South African adolescent and adult populations. The SAEI contains 81 items, which include five subscales: basic skills (nine items, e.g. "I spend a lot of time sending and receiving emails, and I am very good at asking questions), goal-driven behaviour (16 items, e.g. "I make sure that I keep a record of my goals somewhere" and "I set goals for my learning"), creative learning skills (24 items, e.g. "I believe that working in a team makes work easier and "I always take time to think about things I have done"), communication skills (13 items, e.g. "I am good at answering questions, and "I'm very good at organising and presenting information") and business acumen (19 items, e.g. "I understand what it take to succeed in business, and "I know who my customers are going to be one day").

A five-point Likert-type scale was used for subject responses to each of the items $(1=$ does not describe me at all; 5 = best describes me). An exploratory factor analysis provided evidence of construct validity as indicated by the five-factor model, which supports the underlying dimensions of employability described by Beukes (2009). In terms of reliability 
(internal-consistency), Cronbach's alpha coefficients for each subscale range from 0,58 (moderate) to 0.83 (high). In terms of the present study, the overall SAEI scale obtained a reliability coefficient of .89 . The internal consistency reliability coefficients for the five subscales ranged between .74 (creative learning) and .85 (goal-driven behaviour).

The Myers-Briggs Type Indicator (MBTI, Form M) developed by Myers and Briggs (1987) was used to measure participants' personality preference facets (Introversion, Extraversion, Sensing, Intuition, Thinking, Feeling, Judging and Perceiving). The MBTI, Form M, is a self-reporting instrument consisting of 93 items arranged in a forced-choice format. For each item, subjects have two responses to choose from. The objective of the MBTI is to classify an individual into one of the 16 personality types (Myers, et al., 2003). There is general agreement on the MBTI's high levels of face validity (Myers et al., 2003). Myers et al. (2003) report internal consistency reliabilities of .80 for the MBTI Form M scales. Van Zyl and Taylor (2012) also report high internal consistency reliabilities for the sub-scales of the MBTI in the South African context $(\mathrm{E}-1=092 ; \mathrm{S}-\mathrm{N}=088, \mathrm{~T}-\mathrm{F}=0.88, \mathrm{~J}-$ $\mathrm{P}=.91)$. Test-retest reliabilities are thus shown to be high and also show consistency over time.

\section{Procedure}

A cross-sectional, quantitative research approach was followed to achieve the research objective. Questionnaires were manually distributed during a three-day study school and collected by one of the researchers.

\section{Ethical considerations}

Ethical clearance to conduct the research was obtained from the research institution. The participants were invited to participate voluntarily and sign an informed consent form. Privacy, anonymity and confidentiality of all the participants were ensured and honoured.

\section{Data analysis}

Descriptive statistics (means, standard deviations and Cronbach's alpha coefficients), Pearson's product-moment correlations and canonical correlation analysis were performed. The cut-off criteria for canonical factorial loadings $(\geq .30)$ were used to interpret the relative importance of the canonical loadings. The $r^{2}$ type effect size $(1-. \lambda)$ was also 
considered for assessing the magnitude of the overall correlational relationships between the two variates of a canonical function and the practical significance of the predictive ability of the canonical relationship (Hair, Black, Babin \& Anderson, 2010). The participants' age, gender and race were used as controls to explore the relationships between the research variables.

\section{Results}

\section{Descriptive statistics and correlations}

The reliability coefficients reported in Table 1 show acceptable internal consistency reliability of the two scales and the subscales. The overall reliability coefficient of the SAEI was very high $(\alpha=.89)$, and the reliability coefficient for the MBTI variables ranged from .76 to .91 . These coefficients indicated strong overall internal consistency for the two scales.

As can be seen from Table 1, the significant intercorrelations between the SAIE and MBTI variables were small to moderate in practical effect ( $r \geq .09$ to $r \leq .34 ; p \leq .05)$, suggesting no multi-collinearity. The associations between age, gender and race, and the SAEI and MBTI variables were mostly non-significant, small in practical effect and therefore regarded as negligible.

Table 1 furthermore shows significant relationships between most of the subscales of the MBTI and SAEI. Introversion had significant relationships with goal-driven behaviour $(r$ $=-.21$, small effect, $p \leq .01)$, creative learning $(r=-.18$, small effect, $p \leq .05)$ and communication skills $(r=-.21$, small effect, $p \leq .01)$; Extraversion had significant relations with goal-driven behaviour $(r=.22$, small effect, $p \leq .01)$, creative learning $(r=$ .19 , small effect, $p \leq .01)$ and communication skills ( $r=.21$, small effect, $p \leq .01)$; Sensing had a significant relationship with basic skills $(r=-.16$, small effect, $p \leq .05)$; while institution showed a positive relationship with basic skills ( $r=.15$, small effect, $p \leq .05$ ). Judging had a significant relationship with goal-driven behaviour $(r=.34$, medium effect, $p \leq .001)$, creative learning ( $r=.24$, small effect, $p \leq .001)$, communication skills $(r=.15$, small effect, $p \leq .05)$, and business acumen $(r=.13$, small effect, $p \leq .05)$. Perceiving showed significant relationships with goal-driven behaviour $(r=-.33$, medium effect, $p \leq$ 
$.001)$, creative learning $(r=-.18$, small effect, $p \leq .01)$, communication skills $(r=-.14$, small effect, $p \leq .05)$, and business acumen ( $r=-.09$, small effect, $p \leq .05)$.

Insert Table 1 approximately here

\section{Canonical correlations}

Canonical correlation analysis was used to study the multivariate relationships between the five SAEI scores (basic skills, goal-driven behaviour, creative learning, communication skills and business acumen) and the eight MBTI preference facets (Introversion vs Extraversion, Sensing vs Intuition, Thinking vs Feeling and Judging vs Perceiving).

Table 2 shows that the full model was significant using Wilks's multivariate test criterion. Wilks's lambda $(\lambda)=.629$, function $1: \mathrm{F} p=1.95(p=.0001)$. Only the first function of the model was significant and contributed to $22 \%$ of the overall explained variation relative to the function. The full model $r^{2}$ type effect size (yielded by $1-. \lambda$ ) was .37 (large practical effect), indicating that the full model explains an adequate proportion, about $37 \%$, of the variance shared between the two variable sets. The redundancy index results summarised in Table 2 shows that the personality preferences explained $22 \%\left(R \mathrm{c}^{2}=22\right.$; small practical effect) of the variance in self-regulatory employability and was able to predict 54\% (large practical effect) of the proportion of variance in the individual original employability variables.

Table 2 provides the canonical coefficients (weights), canonical structure coefficients $(R \mathrm{c})$, canonical cross-loadings $(R \mathrm{c})$ and squared canonical loadings $\left(R \mathrm{c}^{2}\right)$. Personality preference facets that loaded positively with the employability skills canonical construct were assumed to represent high perceived self-regulatory employability skills. A negative loading were assumed to represent a low perceived employability skill. Using $R \mathrm{c} \geq .30$ as the cut-off threshold for interpreting the results, Table 2 further shows that the Judging (Rc $=.34 ; 12 \%)$ and Perceiving $(R \mathrm{c}=-.35 ; 12 \%)$ personality preferences contributed significantly by explaining the variance especially in goal-driven behaviour $(R \mathrm{c}=.41$; $17 \%)$. 
Insert Table 2 approximately here

\section{Discussion}

Industrial psychologists have long been concerned with employees' psychological wellbeing that enables them to take ownership of their careers and to be proactive agents in managing their careers and improving their employability. In this study, it was sought (1) to ascertain whether a noteworthy relationship exists between the eight set MBTI preference facets (Introversion, Extraversion, Sensing, Intuition, Thinking, Feeling, Judging and Perceiving) and a set of self-regulatory employability skills, and (2) to identify the variables that contribute the most to this relationship. Overall, the results show significant associations between the Judging (positive) and Perceiving (negative) personality preferences and the goal-driven self-regulatory capacity of employability. These findings are in line with research showing that personality is only partially responsible for explaining employability capacities (Coetzee et al., 2014; Cole, Feild, Giles \& Harris, et al., 2009; Potgieter, Coetzee \& Masenge, 2012; Potgieter \& Coetzee, 2013).

The Judging and Perceiving preference dichotomy relates to how individuals prefer to deal with the outer world (Myers et al., 2003). The significant association with goal-driven behaviour could be attributed to the fact that individuals who prefer the Judging mode likes order and a planned and organised approach to life, which seems to explain the drive for setting clear and measurable goals that guide their achievement of career success. Perceiving types seem to have a lower need for goal-setting behaviour. These types are generally individuals who embrace ambiguity, who tend to like a flexible and spontaneous approach to life, and who prefer to keep their options open (Myers et al, 2003). The finding is contrary to the finding made by Coetzee et al (2014) that there is no association between the Judging and Perceiving preferences and career planning skills.

Overall, the results suggest that self-regulatory employability is mostly associated with individuals' orientation towards the outer world, which intuitively makes sense when considering that employability is concerned with the person-career environment interface (Coetzee, 2014; Van der Heijde, 2014). Self-regulation entails proactive career behaviour in setting standards and clear goals, monitoring and bringing about change in achieving career success (Van der Heijde, 2014). In this regard, according to the findings, the 
Judging types seem more prone to demonstrate the self-regulatory employability capacity required to sustain career wellbeing and success in changing contexts, while the Perceiving types may potentially experience certain challenges in this regard. Given the suggestion that personality preferences can be taught and learned by making individuals aware of their dominant preference (Myers et al., 2003), the dichotomy of Judging-Perceiving needs to be developed to help the sample of participants to enhance their self-perceived employability capacities in order to influence their career wellbeing positively.

There were some limitations inherent to this study. First, canonical correlation analysis is a maximisation technique and researchers could therefore have been prone to overestimating the findings owing to the enlargement of linear composites (Hair et al., 2010). Secondly, the sample size of this study was small and was limited to individuals registered for studies in the human resource management field in a distance learning institution. The interpretations of this study are thus limited to this specific group of individuals and not to populations in different occupations, study fields or higher education institutions. It is suggested that the results should be tested on various multicultural populations from various occupational groups, study fields and higher education institutions, as it may further inform theories of the influence personality preferences may have on individual self-perceived employability. Lastly, the cross-sectional nature of this study limits the nature of the data obtained to a specific point in time. As the working environment and facets that contribute to employee well-being constantly change, it would be beneficial to conduct longitudinal research analysis in the shift of levels of employability skills and personality preferences.

\section{Conclusion}

The findings may potentially inform interventions in organisations to enhance the career wellbeing of employees. More specifically, Perceiving types should be made aware of the importance of goal-driven behaviour in managing their employability and career wellbeing. Career discussions about personality preferences and their influence on one's employability and career behaviour may add valuable insights. The results of the study emphasise the importance of considering the influence of personality preferences on employability in enhancing employee career wellbeing, and thus potentially increasing their capacity to adapt to uncertain and changing employment contexts. 


\section{Declaration of conflicting interests}

The authors hereby declare that they have no conflict of interest and that the manuscript has not been submitted elsewhere for review or publication.

\section{Funding}

This research received no specific grant from any funding agency in the public, commercial or non-profit sectors.

\section{References}

ACCI. (2002). Employability skills - An employer perspective. Getting what employees want out of the too hard basket. Kingston, Australia: Australian Chamber of Commerce and Industry.

Ashford, S.J., \& Black, J.S. (1996). Proactivity during organizational entry: The role of desire for control. Journal of Applied Psychology, 81, 199-214.

Barick, M. \& Mount, M. (1991). The big five personality dimensions and job performance: A meta-analysis. Personnel Psychology, 44, 1-29

Baruch, Y. (2004). Transforming careers: from linear to multidirectional career paths. Career Development International, 9(1), 58-73.

Bateman, T.S., \& Crant, J.M. (1993). The proactive component of organizational behavior. Journal of Organizational Behavior, 14, 103-118.

Baumeister, R., \& Leary, M. (1995). The need to belong: Desire for interpersonal attachments as a fundamental human motivation. Psychological Bulletin, 117, 497-529.

Bernston, E., Bernhard-Oettel, C., \& De Cuyper, N. (2007). The moderating role of employability in the relationship between organizational changes and job insecurity. Paper presented at the 13th European Congress of Work and Organizational Psychology, 9-12 May, Stockholm.

Beukes, C. (2009). The relationship between employability and emotional intelligence. Unpublished research report, Department of Industrial and Organisational Psychology, University of South Africa, Pretoria.

Boudreau, J.W., Boswell, W.R., \& Judge, T.A. (1999). Effects of Personality on Executive Career Success in the U.S. and Europe. (CAHRS Working Paper \#99-12). Ithaca, NY: 
Cornell University, School of Industrial and Labor Relations, Center for Advanced Human Resource Studies.

Clarke, M. (2008). Understanding and managing employability in changing career contexts. European Industrial Training, 32(4), 258-284.

Coetzee, M. (2008). Psychological career resources and subjective work experiences of working adults: A South African survey. South African Journal of Industrial Psychology, 34(2), 32-41.

Coetzee, M. (2014). A psychological career resources framework for contemporary career development. In M. Coetzee (ed.), Psycho-social career meta-capacities: dynamics of contemporary career development (pp. 87-122). Dordrecht, the Netherlands: Springer International.

Coetzee, M., \& Beukes, C. (2010). Employability, emotional intelligence and career preparation support satisfaction among adolescents in the school-to-work transition phase. Journal of Psychology in Africa, 20(3): 439-446.

Coetzee, M., \& De Villiers, M. (2010). Sources of job stress, work engagement and career orientations of employees in a South African financial institution. Southern African Business Review, 14(1), 27-57.

Coetzee, M., Schreuder, A.M.G., \& Kotze, C. (2014). Exploring personality preferences in relation to psychological career resources among managerial staff in the Western Cape fast food industry. Journal of Psychology in Africa, 24(4), 308-314.

Cole, M., Feild, H., Giles, W., \& Harris, S. (2009). Recruiters' inferences of applicant personality based on resume screening: do paper people have a personality? Journal of Business Psychology, 24, 5-18.

Crant, J.M. (2000). Proactive behaviour in organizations. Journal of Management, 26, $435-462$.

Cullen, K.L., Edwards, B.D., Casper, W.C., \& Gue, K.R. (2014). Employees' adaptability and perceptions of change-related uncertainty: implications for perceived organizational support, job satisfaction and performance. Journal of Business and Psychology, 29, 269-280.

De Cuyper, N., Bernhard-Oettel, C., Berntson, E., De Witte, H., \& Alarco, B. (2008). Employablity and employees'well-being: Mediation by job insecurity. Applied Psychology: An International Review, 57(3), 488-509. 
De Vries, S., Grundemann, R., \& Van Vuuren, T. (2001). Employability policy in Dutch organizations. The International Journal of Human Resource Management, 12(7), 1193-1202.

De Witte, H. (2006), Job insecurity: Review of the international literature on definitions, prevalence, antecedents and consequences. South African Journal of Industrial Psychology, 31(4), 1-6.

Ebby, L., Butts, M., \& Lockwood, A. (2003). Predictors of success in the era of the boundaryless career. Journal of Organizational Behaviour, 24(6), 689.

Frese, M., \& Fray, D. (2001). Personal initiative: An active performance concept for work in the $21^{\text {st }}$ century. In B.M. Staw \& R.I. Sutton (Eds.), Research in organizational behavior (Vol. 23, pp. 133-187). Amsterdam: Elsevier.

Fugate, M., Kinicki, A.J., \& Blake, E.A. (2004). Employability: A psycho-social construct, its dimensions, and applications. Journal of Vocational Behaviour, 65, 14-38.

Garrety, K. (2007). Beyond ISTJ: A Discourse-Analytic Study of the Use of the MyersBriggs Type Indicator as an Organisational Change Device in an Australian Industrial Firm. Asia Pacific Journal of Human Resources, 45(2), 218-234. http:// dx.doi.org/10.1177/1038411107079117.

Hair, J., Black, W., Babin, B. \& Anderson, R. (2010). Multivariate data analysis. Pearson, NJ: Pearson Education.

Hall, D.T. (2002). Careers in and out of organization. Thousand Oaks, CA: Sage.

Hall, D.T., \& Mirvis, P.H. (1995). The new career contract: Developing the whole person at midlife and beyond. Journal of Vocational Behavior, 47, 269-289.

Higgs, M. (2001). Is there a relationship between the Myers-Briggs Type Indicator and emotional intelligence? Journal of Managerial Psychology, 16(7), 509-533.

Hogan, R., Chamorro-Premuzic, T., \& Kaiser, R.B. (2013). Employability and Career success: Bridging the Gap between theory and reality. Industrial and Organizational Psychology, 6, 3-16.

Jung, C. (1960). The structure and dynamics of the psyche. London: Routledge \& Kegan Paul.

Jung, C. (1971). Psychological types. Princeton, NJ: Princeton University Press.

Jung, C. (1990). Psychological types. Princeton, NJ: Princeton University Press.

Kummerow, J.M., \& Quenk, N.L. (2003). Understanding your MBTI Step II results: A step-by-step guide to your unique expression of type. Mountain View, CA: CPP. 
Kuncel. N.R., Ones, D.S., \& Sackett, P.R. (2010). Individual differences in predictors at work, educational, and broad life outcomes. Personality and Individual Differences, 49, 331-336.

Leary, M.M., Reilly, M.D., \& Brown, F.W. (2008). A Study of Personality Preferences and Emotional Intelligence. Leadership \& Organization Development Journal, 30(5), 421-434. http://dx.doi.org/10.1108/01437730910968697.

Marler, J.H., Barringer, M.W., \& Milkovich, G.T. (2002). Boundaryless and traditional contingent employees: Wolds apart. Journal of Organizational Behavior, 23, 425-453.

Morley, 1. (2001). Producing new workers: Quality, equality and employability in higher education. Quality in Higher Education, 7(2), 131-138.

Myers, I., McCaulley, M., Quenk, N., \& Hammer, A. (2003). MBTI Manual: A guide to the development and use of the Myers-Briggs Type Indicator. Palo Alto, CA: Consulting Psychologists Press.

Myers, P.B. \& Myers, K.D. (1998). Myers-Briggs Tyoe Indicator Form M. Palo Alto, CA: Consulting Psychologists Press.

Pasmore, W.A. (2011). Tipping the balance: Overcoming persistent problems in organizational change. In A.B. Shani, R.W. Woodman, \& W.A. Pasmore (Eds.), Research in organizational change and development (Vol. 19, pp. 259-292). Bradford: Emerald Group Publishing.

Pool, L., \& Sewell, P. (2007). The key to employability: Developing a practical model of graduate employability. Education and Training, 49(4), 227-289.

Potgieter, I.L. \& Coetzee, M. (2013). Employability attributes and personality preferences of postgraduate business management students. South African Journal of Industrial and Organisational Psychology, 39(1).

Potgieter, I.L. (2012). The relationship between self-esteem and employability attributes of postgraduate business management students. South African Journal of Human Resource Management, 10(2), 1-15.

Potgieter, I.L., Coetzee, M. \& Masenge, A. (2012). Exploring employees' personality attributes in relation to their employability attributes in the Business Management field. Journal of Psychology in Africa, 22(4), 583-596.

Pulakos, E.D., Arad, S., Donovan, M.A., \& Plamondon, K.E. (2000). Adaptability in the workplace: Development of a taxonomy of adaptive performance. Journal of Applied Psychology, 85(4), 612-624. 
Rath, T., \& Harter, H. (2010). The economics of wellbeing. Retrieved August 10, 2016, from http://bhcagrebuild.avenet.net/vertical/Sites/\%7BDCAA7F22-7453-4608-83B1FC8B7CADA40D\%7D/uploads/\%7B7F96F3CE-B893-4DF4-98C7ADB8BA5452B3\%7D.PDF.

Rothmann, S. \& Coetzer, E.P. (2003). The big five personality dimension and job performance. South African Journal of Industrial Psychology. 29(1), 68-74.

Rothmann, S. (2014). Flourishing in work and careers. In M. Coetzee (ed.), Psycho-social career meta-capacities: dynamics of contemporary career development (pp. 203-220). Dordrecht: Springer International.

Salovey, P., \& Mayer, J. (1990). Emotional Intelligence. Imagination, Cognition, and Personality, 9, 185-221.

Sinclair, V. (2009). Experiencing career satisfaction and career success over the life span. Retrieved February 2, 2010, from http://www.counsellingdirectory.org,uk/counselloradvice98889.html.

Sverke, M., Hellgren, J., \& Naswall, K. (2002). No security: A meta-analsyis and review of job insecurity and its consequences. Journal of Occupational Health Psychology, $7(3), 242-264$.

Van der Heijde, C.M. (2014). Employability and self-regulation in contemporary careers. In M. Coetzee (ed.), Psycho-social career meta-capacities: dynamics of contemporary career development (pp. 7-18). Dordrecht, the Netherlands: Springer International.

Van Zyl, C.J.J. \& Taylor, N. (2012). Evaluating the MBTI Form M in a South African context. South African Journal of Industrial Psychology, 38(1), 1-15.

Worley, C.G. \& Mohrman, S.A. (2014). Is change management obsolete? Organizational Dynamics, 43, 214-224. 
Table 1 Descriptive statistics, zero-order correlations and internal consistency reliability

\begin{tabular}{|c|c|c|c|c|c|c|c|c|c|c|c|c|c|c|c|c|c|c|c|c|c|}
\hline & & $M$ & SD & $a$ & 1 & 2 & 3 & 4 & 5 & 6 & 7 & 8 & 9 & 10 & 11 & 12 & 13 & 14 & 15 & 16 & 17 \\
\hline Age & 1 & - & - & - & - & & & & & & & & & & & & & & & & \\
\hline Gender & 2 & - & - & - & $-.17^{\star *}$ & - & & & & & & & & & & & & & & & \\
\hline Race & 3 & - & - & - & .06 & .06 & - & & & & & & & & & & & & & & \\
\hline Basic skills & 4 & 3.74 & .80 & .75 & $-.19^{\star *}$ & .10 & $.27^{\star \star *}$ & - & & & & & & & & & & & & & \\
\hline $\begin{array}{l}\text { Goal-driven } \\
\text { behaviour }\end{array}$ & 5 & 4.00 & .70 & .85 & .07 & -.03 & $-.26^{\star * *}$ & .02 & - & & & & & & & & & & & & \\
\hline Creative learning & 6 & 4.14 & .46 & .74 & -.02 & -.07 & -.13 & .13 & $.66^{\star * *}$ & - & & & & & & & & & & & \\
\hline $\begin{array}{l}\text { Communication } \\
\text { skills }\end{array}$ & 7 & 4.10 & .48 & .82 & .03 & $-.15^{*}$ & -.12 & .11 & $.38^{* * *}$ & $.57^{\star \star \star}$ & - & & & & & & & & & & \\
\hline Business acumen & 8 & 4.25 & .47 & .80 & .09 & .05 & .09 & $.16^{*}$ & $.26^{\star * *}$ & $.41^{\star \star *}$ & $.42^{\star \star \star}$ & - & & & & & & & & & \\
\hline Employability: Total & 9 & 4.10 & .36 & .89 & -.05 & -.01 & -.10 & $.40^{\star \star *}$ & $.69^{* * *}$ & $.82^{* \star *}$ & $.78^{\star * *}$ & $.65^{* * *}$ & - & & & & & & & & \\
\hline Introversion & 10 & 4.43 & .68 & .83 & .07 & -.01 & .10 & .03 & $-.21^{* *}$ & $-.18^{*}$ & $-.21^{* *}$ & -.08 & $-.21^{* *}$ & - & & & & & & & \\
\hline Extraversion & 11 & 4.24 & .70 & .81 & -.08 & .05 & -.08 & -.03 & $.22^{* *}$ & $.19^{* *}$ & $.21^{* *}$ & .06 & $.20^{* *}$ & $-.95^{\star \star \star}$ & - & & & & & & \\
\hline Sensing & 12 & 4.23 & .83 & .83 & -.01 & -.02 & -.03 & $-.16^{*}$ & .02 & -.12 & -.05 & -.07 & -.14 & $.14^{*}$ & $-.15^{\star}$ & - & & & & & \\
\hline Intuition & 13 & 4.67 & .64 & .91 & -.04 & -.08 & -.01 & $.15^{\star}$ & -.04 & .08 & .07 & .04 & .11 & -.05 & -.09 & $-.76^{* * *}$ & - & & & & \\
\hline Thinking & 14 & 4.34 & .76 & .77 & -.00 & $-.15^{*}$ & -.09 & .00 & .08 & .09 & .05 & -.14 & .04 & -.03 & .02 & .10 & -.12 & - & & & \\
\hline Feeling & 15 & 4.84 & .74 & .76 & .03 & .13 & $.15^{*}$ & .03 & -.08 & -.11 & -.05 & -.10 & -.06 & .04 & .01 & -.06 & .12 & $-.88^{* * *}$ & - & & \\
\hline Judging & 16 & 4.47 & .67 & .82 & .09 & -.07 & $-.05^{\star}$ & -.13 & $.34^{* * *}$ & $.24^{* * *}$ & $.15^{*}$ & $.13^{*}$ & $.21^{\star *}$ & .08 & -.05 & $.22^{* *}$ & $-.24^{\star \star \star}$ & .01 & .00 & - & \\
\hline Perceiving & 17 & 4.61 & .72 & .84 & -.10 & .12 & .10 & .14 & $-.33^{\star \star *}$ & $-.18^{\star *}$ & $-.14^{*}$ & $-.09^{*}$ & $-.17^{\star}$ & -.03 & .05 & $-.23^{\star *}$ & $.31^{\star \star \star}$ & .02 & .01 &.$-.90^{\star \star \star}$ & - \\
\hline
\end{tabular}


Table 2 Results of the standardised canonical correlation analysis for the first canonical function

\begin{tabular}{lllll}
\hline Variate/variables & $\begin{array}{l}\text { Canonical } \\
\text { coefficients }\end{array}$ & $\begin{array}{l}\text { Structure } \\
\text { coefficient } \\
(\boldsymbol{R} \boldsymbol{c})\end{array}$ & $\begin{array}{l}\text { Canonical } \\
\text { cross- } \\
\text { loadings } \\
(\boldsymbol{R c})\end{array}$ & $\begin{array}{l}\text { Squared } \\
\text { canonical } \\
\text { loadings } \\
\left(\boldsymbol{R c}^{2}\right)\end{array}$ \\
\hline Personality preferences canonical variate & & & \\
variables & & & \\
\hline Introversion & -.48 & -.56 & -.26 & .07 \\
Extraversion & .12 & .53 & .25 & .06 \\
Sensing & .22 & .10 & .05 & .00 \\
Intuition & .27 & .12 & -.05 & .00 \\
Thinking & -.07 & .21 & .10 & .01 \\
Feeling & -.31 & -.26 & -.12 & .01 \\
Judging & .31 & .73 & .34 & .12 \\
Perceiving & -.51 & -.75 & -.35 & .12 \\
\hline Employability canonical variate variables & & & & .02 \\
\hline Basic skills & -.31 & -.27 & -.13 & .17 \\
Goal-driven behaviour & .79 & .89 & .41 & .09 \\
Creative learning & -.03 & .63 & .29 & .08 \\
Communication skills & .41 & .62 & .29 \\
Business acumen & -.13 & .16 & .08 & .01 \\
\hline Overall & & &
\end{tabular}

Overall model fit measures (function 1):

Overall $R c^{2}=.22$

$\mathrm{F}(p)=1.95(p<.0001) ; \mathrm{df}=40 ; 695.86$

Overall proportion: .54

Wilks' Lambda $(\lambda)=.629 * *$

$r^{2}$ type effect size: $1-. \lambda=.371$ (large practical effect)

Redundancy Index (standardised variance of self-regulatory employability explained by personality preferences):

Proportion $=.07$

\section{Notes: $\mathbf{N}=196$.}




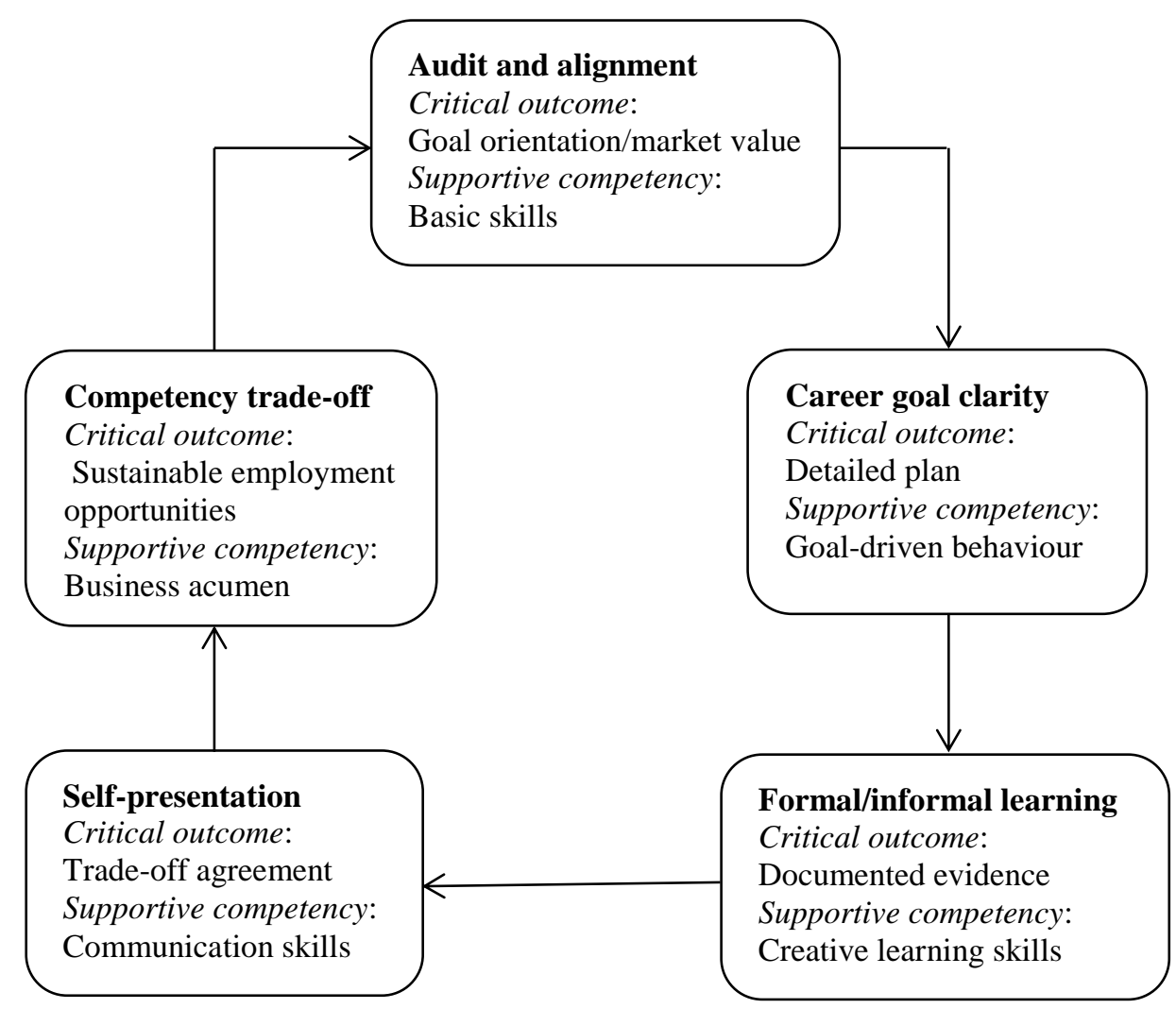

Figure 1 Model of self-regulatory employability (Beukes, 2009) 